\title{
PROFIL PASIEN TUBERKULOSIS PARU DI POLIKLINIK PARU RSUP PROF. Dr. R.D. KANDOU MANADO
}

\author{
Putri Puspitasari ${ }^{1}$, M.C.P Wongkar ${ }^{2}$, Eko Surachmanto ${ }^{2}$ \\ ${ }^{1}$ Kandidat skripsi Fakultas Kedokteran Universitas Sam Ratulangi \\ ${ }^{2}$ Bagian Ilmu Penyakit Dalam BLU RSUP Prof. Dr. R.D. Kandou Manado \\ Email: pputz_puspitasari@yahoo.com
}

\begin{abstract}
Pulmonary tuberculosis in Indonesia is a global health problem and including the third leading cause of death after India and China. In 1992, the WHO has declared TB as a global emergency. The high prevalence of pulmonary tuberculosis caused by a variety of reasons, namely: low socioeconomic, health protection is not sufficient, the lack of public knowledge about pulmonary tuberculosis, treatment cost and the lack of control of tuberculosis cases, the presence of the HIV epidemic, especially in developing countries. Tuberculosis is currently common in productive age and increased mortality, especially in developing countries. This study aims to determine the profile of pulmonary tuberculosis patients in Polyclinics of Pulmonary RSUP Prof. Dr. R.D. Kandou Manado using descriptive observational method. Total sample of 52 patients. Most are between the age range $41-50$ years. Most clinical symptoms of tuberculosis patients was cough on 51 patients. Hemoptysis was found in 17 patients, 12 patients fever and weight loss obtained in 23 patients. Based on work status and patient education obtained samples with the highest education is high school with 23 patients and self-employed with a number of 19 patients. Only 3 patients had a BMI $<18.5$ (underweight) and 35 patients with normal level of albumin. Based on the classification of the highest tuberculosis patient is an overview of category I and laboratory sputum results obtained for 34 patients with smear positive.
\end{abstract}

Keywords: tuberculosis, clinical symptoms, nutritional status, laboratory sputum results.

\begin{abstract}
Abstrak: Tuberkulosis paru di Indonesia merupakan suatu masalah kesehatan dunia dan termasuk penyebab kematian ketiga setelah India dan China. Pada tahun 1992,WHO telah mencanangkan TB sebagai kedaruratan global. Tingginya prevalensi tuberkulosis paru disebabkan oleh berbagai alasan yaitu: sosioekonomi rendah, perlindungan kesehatan yang tidak mencukupi, kurangnya pengetahuan masyarakat tentang penyakit tuberkulosis paru, kurangnya biaya pengobatan dan pengawasan kasus tuberkulosis, adanya epidemi HIV terutama di negara berkembang. Tuberkulosis saat ini banyak menyerang usia produktif dan meningkatkan angka kematian terutama di negara berkembang. Penelitian ini bertujuan untuk mengetahui profil pasien tuberkulosis paru di poliklinik paru RSUP Prof. Dr. R.D. Kandou Manado dengan menggunakan metode deskriptif observasional. Jumlah sampel 52 orang pasien. Pasien laki-laki lebih banyak dibanding dengan pasien perempuan. Rentang usia terbanyak adalah antara 41-50 tahun. Gejala klinis pasien tuberkulosis terbanyak adalah batuk yaitu pada 51 pasien. Hemoptisis didapatkan pada 17 pasien, dispneu terdapat pada 16 pasien, keringat malam 24 pasien, demam 12 pasien dan penurunan berat badan didapat pada 23 pasien. Berdasarkan status pekerjaan dan pendidikan pasien didapatkan sampel dengan pendidikan terakhir terbanyak yaitu SMA dengan jumlah 23 orang pasien dan pekerjaan terbanyak yaitu wiraswasta dengan jumlah 19 orang pasien. Hanya 3 orang pasien yang memiliki IMT < 18,5 (underweight) dan 35 orang pasien dengankadar albumin normal. Berdasarkan klasifikasi pasien tuberkulosis terbanyak adalah kategori I dan hasil gambaran laboratorium sputum didapatkan sebanyak 34 orang pasien dengan BTA positif.
\end{abstract}

Kata kunci: tuberkulosis, gejala klinis, status gizi, gambaran laboratorium sputum. 
Tuberkulosis (TB) merupakan suatu masalah kesehatan dunia terutama negara berkembang. Penyakit ini adalah suatu penyakit infeksius yang disebabkan oleh Mycobacterium tuberculosis, yang merupakan kuman aerob yang dapat hidup terutama di organ paru dan dapat juga ditularkan ke berbagai organ tubuh lainnya. ${ }^{1}$ Hampir 2,2 miliar orang, atau sepertiga dari populasi dunia terinfeksi TB. Kebanyakan orang terinfeksi TB laten, yaitu mereka yang terinfeksi kuman TB namun tidak menjadi sakit karena memiliki sistem kekebalan tubuh yang kuat. $^{2}$

Menurut laporan Organisasi Kesehatan Dunia / World Health Organization (WHO) pada tahun 2011 diperkirakan terdapat hampir 9 juta kasus baru dan 1,4 juta kematian akibat TB, 990.000 kematian dengan human immunodeficiency virus (HIV) negatif dan 430.000 kematian dengan HIV positif. ${ }^{3}$

Berdasarkan data Riset Kesehatan Dasar (Riskesdas) 2010, prevalensi TB paru pada pasien yang pernah didiagnosis dengan tb paru yang berada di lima urutan tertinggi yaitu, Papua 1.441 per 100.000 penduduk, Banten 1.282 per 100.000 penduduk, Sulawesi Utara 1.221 per 100.000 penduduk, Gorontalo 1.200 per 100.000 penduduk, dan DKI Jakarta 1.032 per 100.000 penduduk. Adapun lima provinsi dengan prevalensi TB paru tertinggi yang didapatkan berdasarkan gejala klinis yaitu, Gorontalo 6.992 per 100.000 penduduk, Papua Barat 6.722 per 100.000 penduduk, Nusa Tenggara Timur (NTT) 6.511 per 100.000 penduduk, Sulawesi Tengah 5.367 per 100.000 penduduk, dan Jambi 5.337 per 100.000 penduduk. $^{4}$

Tingginya prevalensi tuberkulosis paru disebabkan oleh berbagai alasan yaitu: sosioekonomi rendah, perlindungan kesehatan yang tidak mencukupi, kurangnya pengetahuan masyarakat tentang penyakit tuberkulosis paru, kurangnya biaya pengobatan dan pengawasan

kasus tuberkulosis, adanya epidemi HIV terutama di negara berkembang. ${ }^{5}$ Faktor-faktor yang dapat mempengaruhi lamanya penyembuhan serta pengobatan pada pasien tuberkulosis paru yaitu, progresisifitas infeksi, diabetes mellitus, HIV, penyakit ginjal, kehamilan, malnutrisi, merokok, alkohol, terapi kortikosteroid, faktor genetik, kurangnya informasi dan pemahaman penderita terhadap penyakitnya, serta faktor sosioekonomi kultural. ${ }^{6}$ Keadaan lingkungan, ventilasi udara di ruangan, lama pajanan, jumlah percik renik, ukuran dan konsentrasi kuman juga mempengaruhi proses infeksi M. tuberkulosis.

Risiko tertular tergantung dari tingkat pajanan dan percikan dahak. Pasien TB paru dengan BTA positif memberikan kemungkinan risiko penularan lebih besar dari TB paru dengan BTA negatif. Risiko penularan setiap tahunnya di tunjukkan dengan Annual Risk of Tuberculosis Infection (ARTI) yaitu proporsi penduduk yang berisiko terinfeksi TB selama satu tahun. ARTI sebesar 1\%, berarti 10 orang diantara 1000 penduduk terinfeksi setiap tahun. ARTI di Indonesia bervariasi antara $1-3 \%^{8}$

Penelitian ini bertujuan untuk mengetahui bagaimana profil penderita tuberkulosis paru di Poliklinik Paru Bagian Ilmu Penyakit Dalam RSUP Prof. dr. R. D. Kandou Manado.

\section{METODE PENELITIAN}

\section{Rancangan Penelitian}

Jenis penelitian yang digunakan adalah deskriptif observasional yaitu mengetahui profil pasien tuberkulosis yang berobat di Poliklinik Paru RSUP Prof. dr. R. D. Kandou Manado. 


\section{Tempat dan Waktu Penelitian}

Lokasi yang akan dilakukan dalam penelitian ini adalah di Poliklinik RSUP Prof. dr. R. D. Kandou Manado yaitu pada bulan Oktober 2013 - Desember 2013.

\section{Populasi dan Sampel Penelitian}

Populasi dalam penelitian ini adalah pasien yang didiagnosa tuberkulosis yang mendapat pengobatan di Poliklinik RSUP Prof. Dr. R. D. Kandou Manado. Sampel yang digunkan adalah seluruh dari jumlah populasi pasien tuberkulosis yang berobat di Poliklinik RSUP Prof. Dr. R.D. Kandou Manado.

\section{HASIL}

Dari hasil penelitian yang dilakukan di Poliklinik Paru RSUP Prof. dr. R.D. Kandou Manado selama periode Oktober hingga Desember 2013, diperoleh data yang disajikan dalam bentuk tabel dan diagram sebagai berikut:

Tabel 2. Karakteristik Sampel Penelitian.

\begin{tabular}{lclll}
\hline Variabel & $\mathrm{N}$ & Min-Max & SB & Rerata \\
\hline Umur & 52 & $19-77$ & 13,335 & 49,33 \\
Status Gizi & & & & \\
IMT & 52 & $15-30$ & 3,304 & 22,18 \\
Albumin & 52 & $2,28-4,7$ & 0,578 & 3,74 \\
\hline
\end{tabular}

Gambar 1. Distribusi Pasien TB berdasarkan Jenis Kelamin.

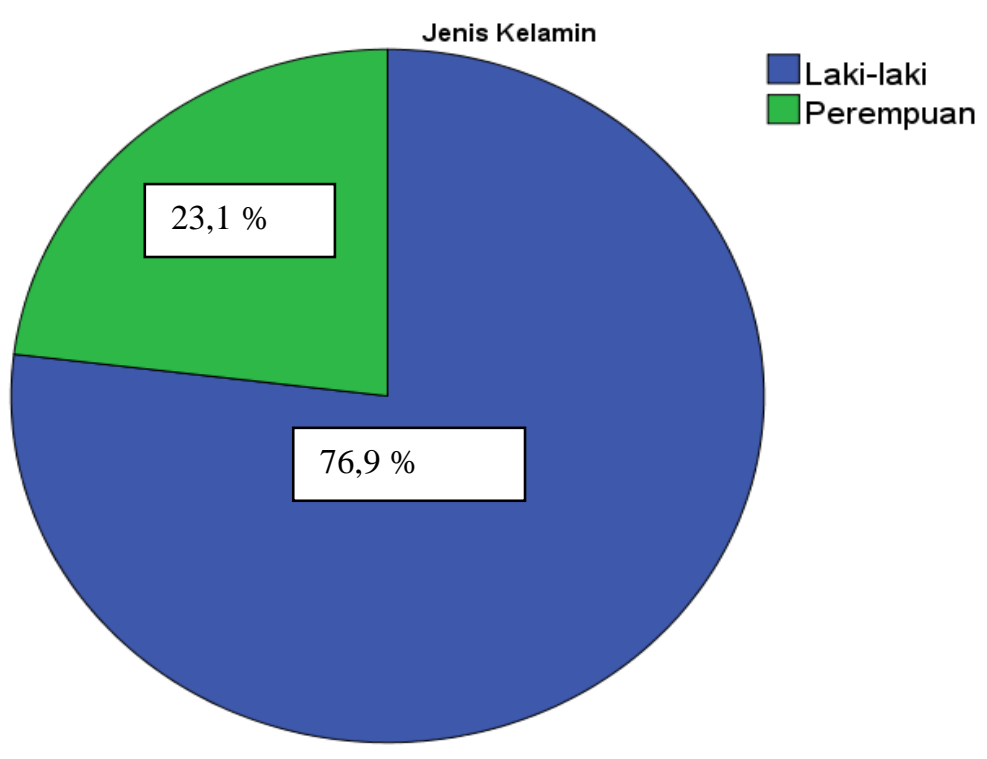

Jumlah sampel 52 orang pasien yang terdiri dari 40 pasien laki-laki (76,9\%) dan 12 pasien perempuan $(23,1 \%)$ dengan umur diantara 19-77 tahun, dan rerata $\pm 13,335$ tahun. Untuk status gizi pasien TB didapatkan hasil IMT diantara 15-30 dengan rerata $\pm 3,304$ dan nilai albumin diantara 2,28-4,7 gram/dL dengan rerata $\pm 0,578$ gram/dL. 
Tabel 3. Distribusi Pasien Tuberkulosis Berdasarkan Gejala Klinis.

\begin{tabular}{lcc}
\hline \multicolumn{1}{c}{ Gejala Klinis } & $\mathrm{N}$ & Presentase \\
\hline Batuk & 51 & $98,1 \%$ \\
Hemoptisis & 17 & $32,7 \%$ \\
Dispneu & 16 & $30,8 \%$ \\
Keringat Malam & 24 & $46,2 \%$ \\
Demam & 12 & $23,1 \%$ \\
Penurunan Berat Badan & 23 & $44,2 \%$ \\
\hline
\end{tabular}

Gejala klinis pasien TB terbanyak adalah batuk yaitu pada 51 pasien $(98,1 \%)$. Hemoptisis didapatkan pada 17 pasien (32,7\%), dispneu terdapat pada 16 pasien (30,8\%), keringat malam 24 pasien (46,2\%), demam 12 pasien (23,1\%), dan penurunan berat badan didapat pada 23 pasien $(44,2 \%)$.

Tabel 4. Distribusi Pasien TB Berdasarkan Umur.

\begin{tabular}{lll}
\hline Umur & $\mathrm{N}$ & Persentasi \\
\hline$<30$ tahun & 5 & $9.6 \%$ \\
$31-40$ tahun & 7 & $13.5 \%$ \\
$41-50$ tahun & 16 & $30.8 \%$ \\
$51-60$ tahun & 14 & $26.9 \%$ \\
$61-70$ tahun & 7 & $13.5 \%$ \\
$>70$ tahun & 3 & $5.8 \%$ \\
Total & 52 & $100.0 \%$ \\
\hline
\end{tabular}

Tabel 5. Distribusi Pasien TB Berdasarkan Pendidikan.

\begin{tabular}{lll}
\hline Pendidikan & $\mathrm{N}$ & Persentasi \\
\cline { 2 - 3 } SD & 10 & $19.2 \%$ \\
SMP & 10 & $19.2 \%$ \\
SMA & 23 & $44.2 \%$ \\
Sarjana & 9 & $17.3 \%$ \\
Total & 52 & $100.0 \%$ \\
\hline
\end{tabular}

Tabel 6. Distribusi Pasien Tuberkulosis Berdasarkan Pekerjaan.

\begin{tabular}{lll}
\hline Pekerjaan & $\mathrm{N}$ & Persentasi \\
\hline Tidak Bekerja & 10 & $19.2 \%$ \\
Pegawai & 12 & $23.1 \%$ \\
Wiraswasta & 19 & $36.5 \%$ \\
Pensiunan & 9 & $17.3 \%$ \\
Petani atau Nelayan & 2 & $3.8 \%$ \\
Total & 52 & $100.0 \%$ \\
\hline
\end{tabular}




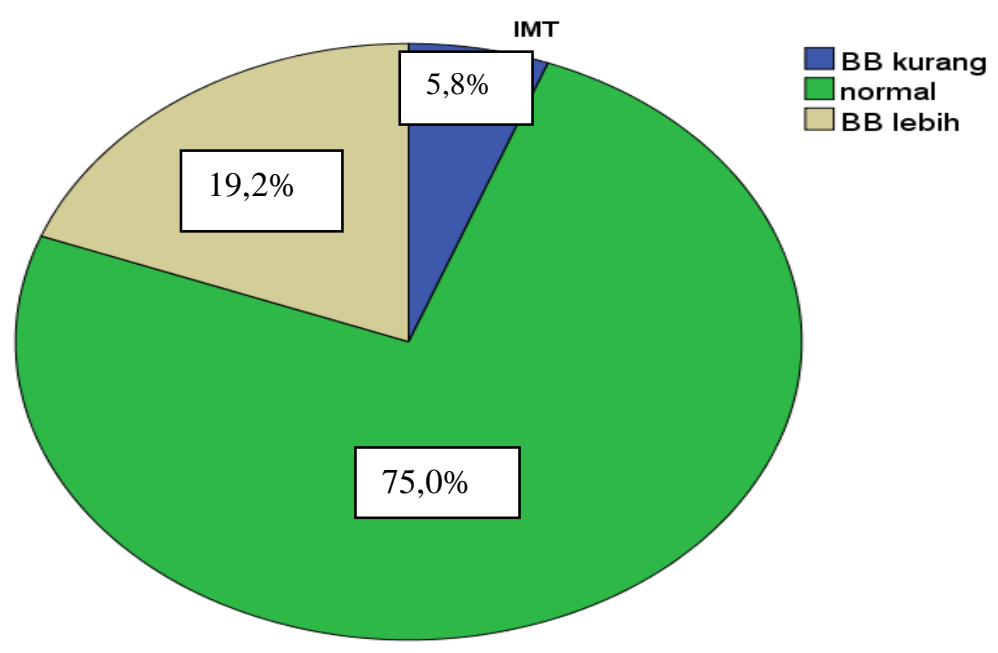

Gambar 2. Distribusi Pasien TB Berdasarkan IMT.

Tabel 7. Distribusi Pasien Tuberkulosis Berdasarkan Nilai Albumin

\begin{tabular}{llc}
\hline Kadar Albumin & $\mathrm{N}$ & Persentasi \\
\hline$<3,5$ gram/dL & 17 & $32.7 \%$ \\
Normal & 35 & $67.3 \%$ \\
Total & 52 & $100.0 \%$ \\
\hline
\end{tabular}

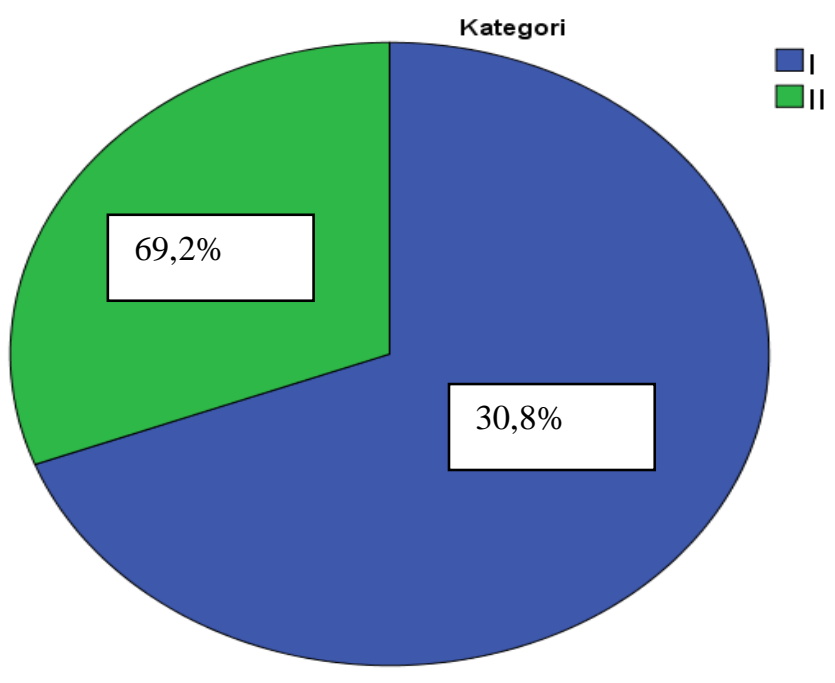

Gambar 3. Distribusi Paien TB Berdasarkan Kategori. 


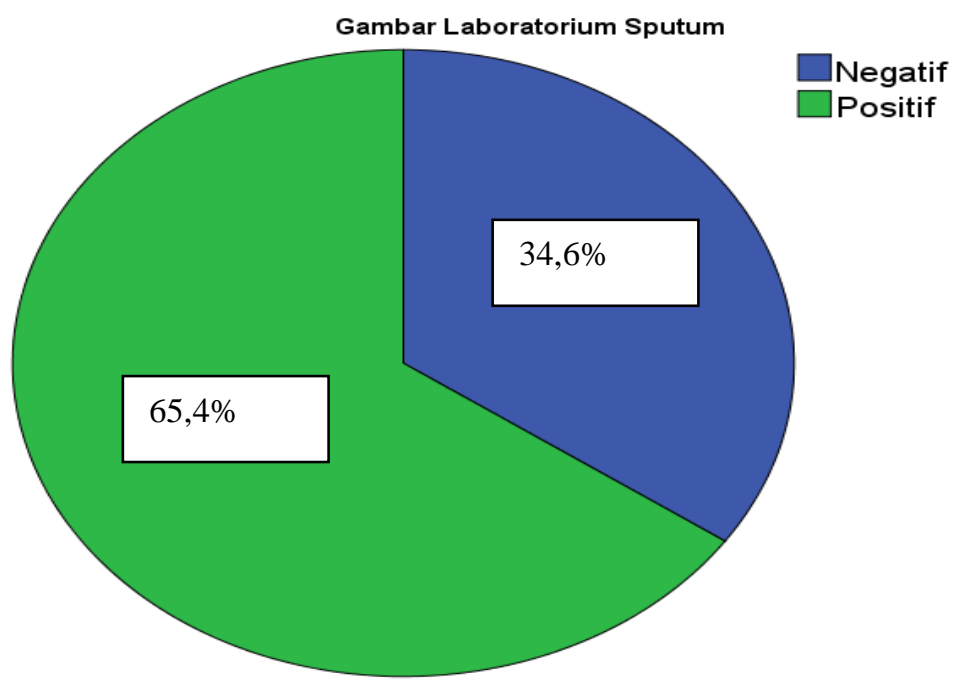

Gambar 4. Distribusi Pasien TB Berdasarkan Gambaran Laboratorium Sputum.

\section{PEMBAHASAN}

Pada penelitian ini, pasien tuberkulosis paru berdasarkan jenis kelamin dari subjek penelitian terbanyak adalah laki-laki yang berjumlah 40 orang pasien (76,9\%) dan perempuan 12 orang pasien (23,1\%). Rentang usia terbanyak adalah antara 41-50 tahun sebanyak 16 orang (30,8\%). Hal yang sama juga ditemukan pada penelitian sebelumnya dimana laki-laki cenderung lebih banyak menderita tuberkulosis paru dibandingkan perempuan hal ini mungkin dikarenakan oleh status sosial dan pekerjaan laki-laki lebih berpotensi untuk terpajan kuman $M$. tuberkulosis. Dan berdasarkan usia penderita tuberkulosis, tingkat penularan penyakit ini lebih tinggi pada usia produktif karena lebih sering berinteraksi dengan lingkungan sekitar. ${ }^{9,11}$

Gejala klinis utama yang paling sering ditemukan dalam penelitan ini adalah batuk yaitu sebanyak 51 orang pasien (98,1\%). Hemoptisis didapatkan pada 17 pasien (33,7\%), dispneu 16 pasien(30,8\%), keringat malam 24 pasien (46,2\%), demam 12 pasien (23,1\%), dan penurunan berat badan 23 pasien (44,2\%). Batuk merupakan gejala yang paling umum terjadi dari TB paru. Penelitian yang sama juga ditemukan oleh Eddy Surjanto dkk dimana batuk merupakan gejala utama yang banyak ditemukan. ${ }^{16}$ Hemoptisis jarang menjadi keluhan utama, namun biasanya keluhan ini merupakan suatu gejala lanjutan yang menunjukkan adanya bakteri yang aktif pada penderita tuberkulosis. Hemoptisis bisa terjadi akibat sisa tuberkulosis bronchiectasis, pecahnya pembuluh darah di rongga paru, atau erosi lesi kalsifikasi ke dalam lumen jalan napas. Dispneu biasanya ditemukan pada penyakit tuberkulosis yang sudah meluas. ${ }^{10}$

Dalam penelitian ini, berdasarkan status pekerjaan dan pendidikan pasien didapatkan sampel dengan pendidikan terakhir terbanyak yaitu SMA dengan jumlah 23 orang pasien dan pekerjaan terbanyak yaitu wiraswasta dengan jumlah 19 orang pasien. Seperti yang telah dijelaskan sebelumnya bahwa lingkungan pekerjaan, sering berinteraksi dengan orang lain dapat mempengaruhi tingkat penularan akibat adanya kontak dengan orang yang menderita TB. ${ }^{11}$ 
Berdasarkan hasil status gizi pada penelitian ini ditemukan 3 pasien yang memiliki IMT $<18,5$ (underweight), 39 pasien dengan IMT 18,5-24,9 (normal) dan 10 pasien dengan IMT $>25$ (overweight). Penelitian ini bertentangan dengan penelitian yang dilakukan sebelumnya oleh Freddy Panjaitan dimana, lebih banyak ditemukan sampel dengan indeks massa tubuh yang $<18,5$ (underweight). ${ }^{13}$ Hal ini dapat disebabkan oleh adanya perbedaan sampel yang digunakan dalam penelitian ini dan penelitian sebelumnya. Status gizi merupakan salah satu faktor yang mempengaruhi terjangkitnya penyakit TB. Dalam penelitian ini sering ditemukan pasien dengan TB paru yang aktif mengalami penurunan berat badan dan penurunan nafsu makan, namun masih memiliki nilai IMT yang normal.

Pada penelitian ini juga ditemukan 17 pasien (32,7\%) dengan kadar albumin $<3,5$ gram/dL dan 35 pasien (67,3\%) dengan kadar albumin normal. Albumin dapat digunakan sebagai indikator keadaan malnutrisi. Kadar albumin yang kurang dapat menunjukkan prognosis buruk terhadap pengobatan. ${ }^{15}$

Dalam penelitian ini klasifikasi yang didapat terbanyak yaitu TB kategori I dengan jumlah 36 pasien (69,2\%) dan kategori II 16 pasien (30,8\%). TB kategori I merupakan kasus baru dengan sputum positif dan TB kategori II merupakan kasus kambuh dimana pasien TB yang sebelumnya pernah mendapatkan pengobatan TB dan telah dinyatakan sembuh atau pengobatan lengkap, didiagnosis kembali dengan BTA positif. ${ }^{17}$

Hasil gambaran laboratorium sputum pada subjek penelitian didapatkan sebanyak 34 orang pasien $(65,4 \%)$ dengan hasil positif dan 18 orang pasien $(34,6 \%)$ negatif. Respons terhadap pengobatan TB harus dipantau dengan kultur dahak pada fase awal pengobatan, jika sputum dahak positif pada tahap awal maka harus diperiksa lagi pada tiga bulan berikut untuk menilai respons TB terhadap pengobatan. ${ }^{12}$ Pemeriksaan sputum pada akhir tahap intensif harus dilakukan untuk mengetahui konversi sputum dari BTA positif menjadi negatif. ${ }^{14}$

\section{KESIMPULAN}

Berdasarkan hasil penelitian yang dilakukan di Poliklinik Paru RSUP Prof.dr. R.D. Kandou Manado selama periode Oktober hingga Desember 2013, maka disimpulkan sebagai berikut:

a. Sebagian besar penderita tuberkulosis paru berjenis kelamin laki-laki dengan presentase 76,9\%.

b. Pasien tuberkulosis terbanyak didapatkan pada usia produktif yaitu pada umur antara 4150 tahun dengan presentase 30,8\%.

c. Gejala klinis umum yang sering terdapat pada pasien tuberkulosis adalah batuk dengan presentase $98,1 \%$.

d. Berdasarkan status pendidikan dan pekerjaan pasien tuberkulosis didapatkan pendidikan terakhir terbanyak yaitu SMA dengan presentase $44,2 \%$ dan pekerjaan terbanyak yaitu wiraswasta dengan presentase $36,5 \%$.

e. Sebagian besar pasien tuberkulosis memiliki IMT 18,5-24,9 (normal). 
f. Pada pemeriksaan albumin ditemukan pasien tuberkulosis dengan nilai albumin normal dengan presentase $67,3 \%$.

g. Berdasarkan klasifikasi pasien tuberkulosis terbanyak adalah kategori I dengan presentase $69,2 \%$.

h. Gambaran laboratorium sputum pasien tuberkulosis banyak didapatkan dengan hasil positif yaitu sebesar $65,4 \%$.

\section{SARAN}

Melihat hasil penelitian ini, maka disarankan untuk perlu dilkukan penelitian dan pengembangan lebih lanjut pada penderita tuberkulosis untuk melihat profil pasien tuberkulosis paru di RSUP Prof. dr. R.D. Kandou Manado.

\section{DAFTAR PUSTAKA}

1. Rab Tabrani. Ilmu Penyakit Paru. Jakarta: Trans Info Media, 2010. Hal.157.

2. American Lung Association. Tuberculosis. American Lung Association State of Lung Disease in Diverse Communities, 2010. Hal. 101.

3. WHO. Global Tuberculosis Report. Geneva: World Health Organization, 2012. Hal.3.

4. Badan Penelitian dan Pengembangan Kesehatan Depkes RI. Riset Kesehatan Dasar 2010. Jakarta: Balitbangkes Depkes RI, 2010.

5. Amin Z, Bahar A. Tuberkulosis Paru. Dalam : Buku Ajar Ilmu Penyakit Dalam. Editor: Sudoyo AW,dkk. Edisi ke-5. Jilid III. Jakarta : Pusat Penerbitan Ilmu Penyakit Dalam FKUI ; 2009. Hal. 2231-32;2233-34

6. Mulyadi, R Suangkupon, I Dermawan. Profil Penderita Tuberkulosis Paru Di Pesisir Pantai Aceh Barat Daya. Jurnal Respirologi. 2011;31;105-6.

7. Luthfi Amir, Putro SG. Tuberkulosis Nosokomial. Jurnal Tuberkulosis Indonesia. 2012.

8. Departemen Kesehatan Republik Indonesia. Pedoman Nasional Penanggulangan Tuberkulosis. Edisi 2. Jakarta: Departemen Kesehatan Republik Indonesia, 2006. Hal. 5.

9. Sihombing H, Sembiring H, Amir Z, Sinaga B. Pola Resistensi Primer Pada Penderita TB Paru Kategori I Di RSUP H. Adam Malik. Medan: Jurnal Respirologi Indonesia, 2012.

10. American Thoracic Society. Diagnostic Standards And Classification Of Tuberculosis In Adults and Children. $2000 . \quad$ Available from: www.uphs.upenn.edu/bugdrug/antibiotic_manual/atstbdx99.pdf.

11. Pertiwi R, Wuryanto MA, Sutiningsih D. Hubungan Antara Karakteristik Individu, Praktik Hygiene dan Sanitasi Lingkungan dengan Kejadian Tuberculosis Di Kecamatan Semarang Utara Tahun 2011. Semarang: Jurnal Kesehatan Masyarakat, 2012.

12. Miglion G.B, Zellweger J.P, Abubakar I, Ibrahim E, Caminero J.A, et al. European Union Standards For Tuberculosis Care. European Respiratory Journal. Vol. 3. 2012.

13. Panjaitan F. Karakteristik Penderita Tuberkulosis Paru Dewasa Rawat Inap di Rumah Sakit Umum Dr. Soedarso Pontianak Periode September-November 2010. Universitas Tanjungpura. 2012. 
14. Zulaikhah ST, Tunjan. Pemantauan Efektivitas Obat Anti Tuberkulosis Berdasarkan Pemeriksaan Sputum Pada Penderita Tuberkulosis Paru. Jurnal Kesehatan. 2010.

15. Martina AD. Hubungan Usia, Jenis Kelamin dan Status Nutrisi dengan Kejadian Anemia Pada Pasien Tuberkulosis. Universitas Diponegoro. 2012.

16. S Eddy, Subagyo SY, Reviono, Harsini, Marsabessy QL. Profil Pasien Koinfeksi TuberkulosisHIV di RS Moewardi Surakarta 2010-2011. Jurnal Respirologi Indonesia. 2012.

17. Soepandi PZ. Diagnosis dan Penatalaksanaan Tb-MDR. Jakarta: Departemen Pulmonologi dan Ilmu Kedokteran Respirasi FKUI, 2010. 